Discussion Paper No. 14-117

\title{
ICT and Economic Growth - Comparing Developing, Emerging and Developed Countries
}

Thomas Niebel

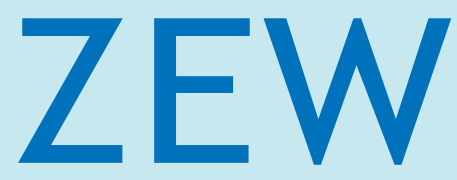

Zentrum für Europäische Wirtschaftsforschung $\mathrm{GmbH}$

Centre for European Economic Research 
Discussion Paper No. 14-117

\title{
ICT and Economic Growth - Comparing Developing, Emerging and Developed Countries
}

\author{
Thomas Niebel
}

Download this ZEW Discussion Paper from our ftp server:

http://ftp.zew.de/pub/zew-docs/dp/dp14117.pdf

Die Discussion Papers dienen einer möglichst schnellen Verbreitung von neueren Forschungsarbeiten des ZEW. Die Beiträge liegen in alleiniger Verantwortung der Autoren und stellen nicht notwendigerweise die Meinung des ZEW dar.

Discussion Papers are intended to make results of ZEW research promptly available to other economists in order to encourage discussion and suggestions for revisions. The authors are solely responsible for the contents which do not necessarily represent the opinion of the ZEW. 


\title{
ICT and Economic Growth - Comparing Developing, Emerging and Developed Countries
}

\author{
Thomas Niebel* \\ ZEW Mannheim
}

December 2014

\begin{abstract}
This paper analyzes the impact of information and communication technologies (ICT) on economic growth in developing, emerging and developed countries. It is based on a sample of 59 countries for the period 1995 to 2010. Various panel data regressions confirm the positive relationship between ICT capital and GDP growth. The regressions for the subsamples of developing, emerging and developed countries do not reveal statistically significant differences of the output elasticity of ICT between these three country groups.
\end{abstract}

Keywords: ICT, Economic Growth

JEL Classification Numbers: E22, J24, O47

${ }^{*}$ Centre for European Economic Research (ZEW) Mannheim, P.O. Box 1034 43, 68034 Mannheim, Phone: +49-6211235-228, Fax:-333, E-mail: niebel@zew.de. For further information on projects of the author see www.zew.de/staff_tni as well as the ZEW annual report on www.zew.de/en. The author thanks James Binfield, Marianne Saam and Patrick Schulte as well as participants at the 33rd IARIW General Conference in Rotterdam for helpful comments and suggestions. All remaining errors are mine. 


\section{Introduction}

Productivity growth lays the foundation for improvements in the standard of living. ${ }^{1}$ Investments in information and communication technologies (ICT) are seen as a key driver of productivity growth. This relationship has been extensively studied for developed countries at the firm, industry and country level with the majority of studies showing the productivity effect of ICT as positive and economically significant. ${ }^{2}$ Recent literature reviews by Draca et al. (2007), Van Reenen et al. (2010), and Cardona et al. (2013) list a comprehensive set of studies applying different methodologies. To date there is rather weak and ambiguous empirical evidence on the contribution of ICT investments on economic growth for emerging and especially developing countries. Despite the rather ambiguous empirical evidence, the World Bank (2012) takes an optimistic view stating that "Information and communication technologies (ICTs) have great promise to reduce poverty, increase productivity, boost economic growth (...)". The weak and ambiguous empirical evidence of the impact of ICT in developing countries may largely be driven by the lack of high quality micro and macro level data sets on ICT for these countries.

A priori, there may be valid reasons why the impact of ICT on growth in developing and emerging countries is different than in developed countries. On the one hand, developing and emerging countries might be lacking absorptive capacities like an appropriate level of human capital or other complementarity factors such as $\mathrm{R} \& \mathrm{D}$ expenditures ${ }^{3}$ and therefore gain less than developed countries from investments in ICT. On the other hand, ICT could enable developing and emerging countries to 'leapfrog' traditional methods of increasing productivity as mentioned by Steinmueller (2001). The additional productivity gains could be triggered by "ICT-related spillovers or network effects" 4 as ICT may lower transaction costs and speed up the process of knowledge creation. ${ }^{5}$ But these network effects may be more pronounced "when many firms in a region or industry are using similar levels or types of ICT". 6

This paper contributes to the literature in several ways. Section 2 reviews the current empirical literature on the impact of ICT on economic growth, focusing on differences in methodologies, data sources and sample periods. Section 3 describes the unique features of the data set used for the empirical work. The Conference Board Total Economy Database (The Conference Board, 2014a), the main source, contains annual data for GDP, ICT and non-ICT capital services as well as labor services to control for changes in human capital. In contrast to previous studies, the empirical work is based on these capital and labor services which are a more appropriate measure than stock variables. The sample for the empirical analysis consists of 59 developing, emerging and developed countries for 1995-2010 and thus covers more countries and years than previous studies were able to. This rich, high quality data set allows clarification of the previous empirical results. Based on this data, Section 4 presents the results including a comparison of the estimated coefficients for the output elasticity of ICT for the pooled sample and the three country subgroups.

The results for the full sample of countries confirm the positive contribution of ICT to economic

\footnotetext{
${ }^{1}$ See e.g. Timmer et al. (2010, p. 18).

${ }^{2}$ Cardona et al. (2013, p. 109).

${ }^{3}$ Keller (2004, p. 774).

${ }^{4}$ Stiroh (2002, p. 43).

${ }^{5}$ Pilat (2004, pp.57-58).

${ }^{6}$ Draca et al. (2007, p. 106).
} 
growth with an output elasticity of about 10 percent, exceeding the factor compensation share by a large amount. ${ }^{7}$ The estimates with sub-samples for the three country groups only reveal small differences between developing, emerging and developed countries. Thus, the results indicate that developing and emerging countries are not gaining more from investments in ICT than developed economies, questioning the 'leapfrogging' through ICT argument.

\section{Related Literature}

The macro-level empirical work on the relationship between ICT and economic growth is based on growth accounting and econometric studies. Several growth accounting studies reveal economically significant contributions of ICT capital to economic growth after the mid 1990s in developed economies. These studies by Oliner and Sichel (2000), Jorgenson and Stiroh (2000) and Oliner and Sichel (2002) focused on the productivity effects of ICT in the US because "European statistics offices' published industry data on ICT assets lag behind the US". ${ }^{8}$ The work by Inklaar et al. (2005) compared the ICT contribution of the US and the EU4 consisting of France, Germany, the Netherlands and the United Kingdom showing higher contributions for the US than the EU4 during the period 1979 to 2000. With the release of the EU KLEMS database (O'Mahony and Timmer, 2009), cross-country studies like Inklaar et al. (2008), Van Ark et al. (2008), Strauss and Samkharadze (2011) as well as Timmer et al. (2011) appeared, showing substantial sectoral and cross-country heterogeneity with respect to the contribution of ICT on labor productivity growth in developed countries.

In the past decade, a number of macro-level econometric studies on ICT and productivity in developed countries have been carried out. Stiroh (2002) surprisingly finds a negative output elasticity of ICT capital in his pooled OLS and IV regressions based on US manufacturing industries data for the years 1984-1999. With an updated data set and more detailed industry breakdown, Stiroh (2005) reports positive coefficients of ICT capital in the production function regressions. Based on dynamic panel data estimations, O'Mahony and Vecchi (2005) as well as Dimelis and Papaioannou (2011) show that there is a significant effect of ICT capital on output growth for both the UK and the US. Dahl et al. (2011) confirm these findings for eight European countries using EU KLEMS data (O'Mahony and Timmer, 2009).

Another strand of the literature focuses on just communication technology (CT). Roller and Waverman (2001) find a causal relationship between CT and GDP for 21 OECD countries. Czernich et al. (2011) support the finding by Roller and Waverman (2001) on the importance of communication technology. Based on a panel of 20 OECD countries, they provide empirical evidence that increasing broadband penetration raises GDP growth rates. More comprehensive literature reviews with a focus on developed countries include Draca et al. (2007), Van Reenen et al. (2010), Biagi (2013) and Cardona et al. (2013).

A priori, it is not clear whether the impact of ICT on economic growth in emerging and developing countries is larger than in developed countries. Steinmueller (2001, p. 194) points out that "ICTs have the potential to support the development strategy of leapfrogging, i.e. bypassing some of the processes of accumulation of human capabilities and fixed investment in order to narrow the gaps in

\footnotetext{
$\overline{7}$ This difference is smaller in the IV regressions.

8 Draca et al. (2007, p. 112).
} 
productivity and output that separate industrialized and developing countries." Whether this strategy is successful crucially depends on the absorptive capacities ("the ability and effort of workers and managers to apply new technology"9) of the emerging and developing countries (see e.g. Keller 1996, Keller 2004 and Henry et al. 2009). The report by the United Nations (2011, pp. 71-78) lists a variety of examples, why ICTs may have a strong(er) impact on economic performance in emerging and developing countries. First of all, investments in ICT may decrease the administrative burden of firms through the introduction of e-government applications. Furthermore, ICT can be used for training and advisory services. It also enhances access to relevant information. Mobile money services, as a tool to save travel time and to reduce transaction costs, are particularly important to micro- and small enterprises. None of these ICT services and applications are specific to emerging and developing countries. But in these countries, ICT often provides services that were previously not available in either the digital or the non-digital economy.

The empirical macro-level literature on ICT and growth in developing and emerging countries examines differing country groups and time periods which narrows the comparability and generalizability of the results. Dewan and Kraemer (2000) find a positive effect of the ICT capital stock on GDP growth in developed countries, whereas the ICT coefficient for developing countries is insignificant. The authors explain this finding by potentially missing 'IT-enhancing complementarity factors' like human capital. The estimation is performed with a panel of 36 countries (14 developing and 22 developed countries) for the years 1985 to 1993. As this period was just the start of the rapid diffusion of ICT in developed countries, it was probably to early to see any (economically) significant effects in developing countries. Pohjola (2002), with data on 42 countries within the period 1985-1999, does not find any significant relationship between ICT and economic growth in either the full sample, or any of the country subgroups. These results are possibly driven by the fact that the ICT input variable is measured as the share of nominal ICT investment in GDP, which does not incorporate any quality improvements of ICT over time. Papaioannou and Dimelis (2007) show that the impact of the ICT capital stock on labor productivity growth is stronger in developed than in developing countries. Their analysis is based on an Arellano and Bond (1991) panel data estimator applied to a sample of 22 developed and 20 developing countries for the period 1993 to 2001. Based on the same data but with a refined econometric approach and the inclusion of foreign direct investment (FDI) as an additional control variable, which is seen as an important channel for technology diffusion, ${ }^{10}$ Dimelis and Papaioannou (2010) report that the impact of ICT is stronger in developing than in developed countries. The study by Yousefi (2011) uses World Bank data for the period 2000 to 2006 and finds an insignificant impact of ICT capital investment on output growth for developing countries. The paper by Dedrick et al. (2013) has the most recent and comprehensive data so far. Their data set consists of 45 upper-income developing and developed countries for the period 1994 to 2007. Their set of so-called 'upper-income developing countries' are comparable to the emerging countries in the present study. They provide econometric evidence for the contribution of ICT to growth for both developing and developed countries with slightly larger output elasticities of ICT stock in developed than in the upper-income developing countries. As mentioned before, the rather ambiguous empirical

\footnotetext{
${ }^{9}$ Kneller (2005).

${ }^{10}$ See e.g. Keller (2004, p. 752).
} 
evidence so far might be explained by different analytical approaches and the use of data sets covering different countries and time periods. ${ }^{11}$

Apart from the econometric analyses, several growth accounting studies by Jorgenson and $\mathrm{Vu}(2005$, 2010, 2011) focus on specific regional groups of countries like 'Developing Asia' and Latin America and therefore implicitly perform a comparison of the contribution of ICT to growth in developing, emerging and developed countries. The same applies to $\mathrm{Vu}$ (2011), who uses data on penetration rates of personal computers, mobile phones and internet users in 107 developing, emerging and developed countries to investigate the impact of ICT on growth, but does not distinguish between these country groups.

Furthermore, a number of micro-level studies analyze the impact of ICT on productivity for certain developing and emerging countries. Aker and Mbiti (2010) discuss, based on the fact that mobile phone usage in Sub-Saharan Africa has grown significantly over the past decade, the economic impact of this rapid diffusion. Commander et al. (2011) find a positive relation between ICT capital and the productivity of firms in Brazil and India.

\section{Data and Methodology}

The primary data source for the analysis is the Conference Board Total Economy Database ${ }^{12}$ (The Conference Board, 2014a). It was originally developed by the Groningen Growth and Development Centre $^{13}$ and since 2007 has been maintained by the Conference Board. The database contains annual data for i.a. GDP, ICT and non-ICT capital services as well as labor services for 123 countries. Output data are available for the period 1950 to 2013, whereas capital input and detailed labor input data are generally only available for a subset of countries for the years 1990 to 2013 . The final data set for the empirical analysis consists of 59 countries for the period 1995 to 2010 with a total of 893 observations. There are two reasons for restricting the sample to the period 1995-2010. First, years prior to 1995 often show missing values for the ICT input variables especially in developing countries. Second, capital input data of the Total Economy Database after 2010 are often inferred from different sources or calculated with a slightly different methodology, which could reduce the overall data quality for the most recent years. Further control variables for the robustness checks are taken from the World Bank World Development Indicators (WDI). ${ }^{14}$

\subsection{Categorization of Countries}

As the primary goal of this empirical work is to compare the contribution of ICT to economic growth for developing, emerging and developed countries, it is necessary to do divide the total sample into three reasonable subsamples. The definition of the country groups is usually based on GDP/GNI per capita or more general indicators like the literacy rate of the countries. The threshold variable chosen in this empirical application is GDP per capita in 1995 expressed in purchasing power parity

\footnotetext{
${ }^{11}$ In contrast to the one-time compilation of data sets used in previous studies, the present empirical work is based on an annually updated publicly available data set on ICT and economic growth. See Section 3 for details.

${ }^{12}$ To be precise, I use the March 2014 update of the Conference Board Total Economy Database January 2014 release. See https://www. conference-board.org/retrievefile.cfm?filename=TED-Change-Notes.pdf\&type=subsite. I thank Klaas De Vries for providing this update covering the majority of errors I found in the January 2014 release.

${ }^{13}$ See http://www.rug.nl/research/ggdc/data/total-economy-database- .

${ }^{14}$ World Bank (2014).
} 
(PPP) adjusted US Dollars of 2013. As shown in Table 3.1, there are 18 developing countries, 22 emerging and 19 developed countries. According to this definition, countries with less than 6,500 2013 US Dollars GDP per capita are classified as developing countries, and all countries with more than 23,000 2013 US Dollars GDP per capita are classified as developed countries. There is a quite large gap in GDP per capita between Peru, as the developing country with the largest GDP per capita, and South Africa as the emerging country with the smallest GDP per capita. The same is true for the split between emerging and developed countries. Portugal as the emerging country with the largest GDP per capita and Ireland as the developed country with the smallest GDP per capita differ in this value by more than 20 percent. A threshold test as described in Hansen (2000) confirms the threshold between developing and emerging countries. ${ }^{15}$ The GDP per capita values of each country at the end of the sample period (2010) are reported in Table A.8 in the Appendix.

Table 3.1: List of Countries by Group: Developed $>23000$ of 2013 US $\$$ GDP per Capita, Developing $<6500$ of 2013 US\$ GDP per Capita in Year 1995

\begin{tabular}{|c|c|c|c|c|c|c|c|c|c|c|c|}
\hline \multicolumn{4}{|c|}{ Developed } & \multicolumn{4}{|c|}{ Emerging } & \multicolumn{4}{|c|}{ Developing } \\
\hline 1. & Australia & AUS & 33,075 & 1. & Argentina & ARG & 10,442 & 1. & Bangladesh & BGD & 998 \\
\hline 2. & Austria & AUT & 33,166 & 2. & Brazil & BRA & 7,770 & 2. & Bolivia & BOL & 3,529 \\
\hline 3. & Belgium & BEL & 31,928 & 3. & Bulgaria & BGR & 7,244 & 3. & Cameroon & CMR & 1,740 \\
\hline 4. & Canada & CAN & 33,055 & 4. & Chile & CHL & 10,110 & 4. & China & $\mathrm{CHN}$ & 2,646 \\
\hline 5. & Denmark & DNK & 33,922 & 5. & Colombia & $\mathrm{COL}$ & 7,118 & 5. & Egypt & EGY & 3,611 \\
\hline 6. & Finland & FIN & 26,062 & 6. & Costa Rica & CRI & 9,013 & 6. & India & IND & 1,704 \\
\hline 7. & France & FRA & 30,257 & 7. & Czech Republic & $\mathrm{CZE}$ & 17,647 & 7. & Indonesia & IDN & 3,510 \\
\hline 8. & Germany & $\mathrm{DEU}$ & 32,232 & 8. & Ecuador & $\mathrm{ECU}$ & 6,733 & 8. & Jordan & JOR & 3,998 \\
\hline 9. & Ireland & IRL & 23,913 & 9. & Hungary & HUN & 13,210 & 9. & Kenya & KEN & 1,297 \\
\hline 10. & Italy & ITA & 30,389 & 10. & Iran & IRN & 7,742 & 10. & Morocco & MAR & 2,534 \\
\hline 11. & Japan & JPN & 33,270 & 11. & Jamaica & JAM & 10,734 & 11. & Nigeria & NGA & 1,123 \\
\hline 12. & Netherlands & NLD & 33,811 & 12. & Malaysia & MYS & 10,534 & 12. & Pakistan & PAK & 2,034 \\
\hline 13. & New Zealand & NZL & 25,146 & 13. & Mexico & MEX & 11,025 & 13. & Peru & PER & 5,570 \\
\hline 14. & Norway & NOR & 44,618 & 14. & Poland & POL & 10,255 & 14. & Philippines & PHL & 2,768 \\
\hline 15. & Spain & ESP & 24,720 & 15. & Portugal & PRT & 19,041 & 15. & Senegal & SEN & 1,264 \\
\hline 16. & Sweden & SWE & 30,034 & 16. & Slovak Republic & SVK & 12,203 & 16. & Sri Lanka & LKA & 2,698 \\
\hline 17. & Switzerland & $\mathrm{CHE}$ & 39,646 & 17. & Slovenia & SVN & 18,234 & 17. & Tunisia & TUN & 4,738 \\
\hline 18. & United Kingdom & GBR & 29,972 & 18. & South Africa & $\mathrm{ZAF}$ & 6,521 & 18. & Vietnam & VNM & 1,655 \\
\hline \multirow[t]{4}{*}{19.} & United States & USA & 40,427 & 19. & South Korea & KOR & 17,429 & & & & \\
\hline & & & & 20. & Thailand & THA & 7,118 & & & & \\
\hline & & & & 21. & Turkey & TUR & 8,484 & & & & \\
\hline & & & & 22. & Venezuela & VEN & 9,970 & & & & \\
\hline
\end{tabular}

\subsection{Outlier Detection}

There are multiple reasons for outlier problems within such a rich cross-country data set. One could be a break in the input data series by switching from one to another data source. This will clearly affect the growth rate of e.g. labor input. Another problem might be general measurement issues, especially in developing countries, due to a lack of resources for the national statistical offices. E.g. Klasen and Blades (2013) argue that "the measurement of economic and social performance has not

\footnotetext{
${ }^{15}$ The test was conducted by the Stata package thresholdtest.ado available at http://www.ssc.wisc.edu/ bhansen/ progs/progs_threshold.html - version March 24, 2014.
} 
kept pace with the apparent drastic improvements in that performance in recent years."

To account for breaks in data series and more general data errors, I use a five step approach. First, I drop countries with erroneous or implausible data during the whole period. This reduces number of countries with data on ICT input from 68 to 59 countries. ${ }^{16}$ The next step is to drop the single observations of the remaining 59 countries with obvious data errors such as a zero ICT capital compensation share (12 observations). Visual inspection of year by year scatter plots between the GDP growth rate and the growth rates of factor input variables revealed 11 additional problematic observations. The fourth step is to calculate the so-called DFBETA ${ }^{17}$ values. The idea behind this method is to calculate the impact of the $i$ th observation on the regression coefficient and drop the observations with abnormal high impact (9 observations dropped). The methodology proposed by Hadi (1992, 1994) is another commonly used approach to detect outliers in the empirical literature. ${ }^{18}$ This fifth step detects another 12 observations as outliers. The complete list of the 44 dropped observations and the approach that identified the outlier is available in Table A.7.

\subsection{Capital and Labor Input Variables}

In contrast to previous studies, the empirical work is based on capital services instead of capital stocks. Capital services are a more appropriate measure than capital stocks. This is, e.g., emphasized by Inklaar and Timmer (2013, p13): "A capital services measure would reflect that shorter lived assets have a larger return in production, as indicated by the user cost of capital of each asset". ICT capital services as well as non-ICT capital services are calculated as the growth rates of the stocks of the single assets (information technology equipment, communication technology equipment and software for ICT) weighted by their factor shares in total ICT (non-ICT) capital compensation. The labor input variable is the growth rate of labor services. It is the sum of the growth rate of the labor composition index and the growth rate of labor quantity. The growth rate of the labor composition reflects changes in human capital. It is constructed ${ }^{19}$ as the growth rate of the share of different skill-level groupings in the labor force weighted by their share in total labor compensation. The definition of the growth rate of labor quantity differs between countries. In the more advanced economies, it is the growth rate of total hours worked. In contrast, the labor quantity for less developed countries is usually based on the employment growth rate. These two methodologies do not lead to any differences as long as the average hours worked per person do not change over time. ${ }^{20}$

Nearly all developing and some of the emerging countries are lacking data for labor compensation. The ad hoc approach of the The Conference Board (2014a) is to assume a labor compensation share in total factor compensation of 0.5. This assumption is justified by the fact that in economies where capital is scarcer, the returns for capital should be higher and the returns for labor smaller. ${ }^{21}$ As the labor compensation is not directly included in the regression, this does not influence the estimated output

\footnotetext{
${ }^{16}$ The countries not in the sample are Algeria (implausible labor services growth rates), Greece (overall data quality issues), Hong Kong and Singapore (very specific export oriented type of economy), Israel, Romania and the Russia Federation (implausible non-ICT capital services growth rates), Taiwan (no data on export share) as well as Uruguay (implausible ICT capital services growth rates).

${ }^{17}$ See e.g. Temple (2000).

${ }^{18}$ See e.g. Harbaugh et al. (2002), Durham (2004) and Ardizzi et al. (2014).

${ }^{19}$ See The Conference Board (2014b) page 5.

${ }^{20}$ See The Conference Board (2014b) page 2.

${ }^{21}$ See The Conference Board (2014b) page 12. See also Tables 3.2, 3.3 and 3.4.
} 
elasticities of ICT- and non-ICT capital. However, the potentially underestimated labor compensation share in developing countries might affect the comparison between the output elasticity of ICT and the growth accounting based ICT compensation share.

\subsection{Descriptive Statistics}

Table 3.2: Summary Statistics: Developing Countries - 1995-2010

\begin{tabular}{|c|c|c|c|c|c|c|}
\hline & $\mathrm{N}$ & Mean & Median & $\mathrm{SD}$ & Min & Max \\
\hline GDP per Capita & 280 & 3,325 & 3,085 & 1,757 & 998 & 9,009 \\
\hline$\Delta \ln (\mathrm{GDP})$ & 280 & 5.1 & 5 & 2.5 & -2.3 & 14 \\
\hline$\Delta \ln (\mathrm{ICT}$ Cap. Serv $)$ & 280 & 18 & 16 & 8.1 & -.46 & 44 \\
\hline$\Delta \ln ($ N.ICT Cap. Serv.) & 280 & 4.8 & 3.7 & 3 & -.56 & 13 \\
\hline$\Delta \ln ($ Labor Serv. $)$ & 280 & 2.8 & 2.7 & 1.8 & -2.9 & 10 \\
\hline$\Delta \ln ($ Labor Composition $)$ & 280 & .25 & .28 & .16 & -.12 & .73 \\
\hline$\Delta \ln ($ Labor Quantity $)$ & 280 & 2.6 & 2.4 & 1.9 & -3.2 & 10 \\
\hline$\Delta \ln ($ Employees $)$ & 280 & 2.5 & 2.4 & 1.8 & -5 & 9.5 \\
\hline$\Delta \ln ($ Hours Worked $)$ & 46 & 2.8 & 2.2 & 2.5 & -3.2 & 10 \\
\hline Exports \% GDP & 280 & 30 & 29 & 13 & 10 & 72 \\
\hline ICT Compensation Share & 280 & .041 & .037 & .021 & .009 & .11 \\
\hline Non-ICT Compensation Share & 280 & .46 & .46 & .024 & .39 & .54 \\
\hline Labor Compensation Share & 280 & .5 & .5 & .015 & .42 & .57 \\
\hline
\end{tabular}

Source: The Conference Board (2014a) and World Bank (2014), own calculations.

Tables 3.2, 3.3 and 3.4 report descriptive statistics of the three country subsgroups for the sample period 1995 to $2010 .{ }^{22}$ The average gross domestic product (GDP) per capita ${ }^{23}$ in developing countries is 3,325 US Dollars with the minimum value just below 1000 US Dollars (the value for Bangladesh in 1995) and the maximum for Peru in 2010 with 9,009 US Dollars. For the emerging countries, this average is 13,367 US Dollars ranging from 6,433 US Dollars to 31,451 US Dollars. As the GDP per capita value of 1995 defines the three country subgroups, we can see the highest average GDP per capita with 38,044 US Dollars for the developed countries shown in Table 3.4. The average growth rate of GDP is 5.1 percent in developing, 3.6 percent in emerging and 2.4 percent in developed countries indicating at least some kind catch-up effect.

ICT capital services as the main variable of interest shows a comparable average growth rate of 18 and 17 percent in developing and emerging countries. With an average growth rate of just 11 percent, this number is much lower in the group of developed economies. The average growth rates of non-ICT capital services are much lower than those of ICT capital services, with the highest value of 4.8 percent in developing countries and the lowest value of 2.3 percent again in the developed economies. The labor services growth rates range from 1.3 percent in developed countries to 2.8 percent in developing countries. It is the sum of the growth rate of labor composition and labor quantity. The largest average growth rate of labor composition (i.e. the accumulation of human capital) occurs in emerging countries, followed by the developed countries. The labor composition growth rate in developing countries is only one half of the growth rate in the emerging countries. The average factor compensation share of

\footnotetext{
${ }^{22}$ Descriptive statistics of the full sample are shown in Table A.6 in the Appendix.

${ }^{23}$ Expressed in purchasing power parity (PPP) adjusted US Dollars of 2013.
} 
Table 3.3: Summary Statistics: Emerging Countries - 1995-2010

\begin{tabular}{lrrrrrr}
\hline & $\mathrm{N}$ & Mean & Median & SD & Min & Max \\
\hline GDP per Capita & 316 & 13,367 & 11,486 & 5,915 & 6,433 & 31,451 \\
$\Delta \ln ($ GDP) & 316 & 3.6 & 3.9 & 3 & -8 & 10 \\
$\Delta \ln$ (ICT Cap. Serv) & 316 & 17 & 17 & 7.3 & 1 & 40 \\
$\Delta \ln$ (N.ICT Cap. Serv.) & 316 & 3.9 & 3.6 & 2.6 & -1.2 & 13 \\
$\Delta \ln$ (Labor Serv.) & 316 & 1.9 & 1.9 & 2.5 & -4.1 & 10 \\
$\Delta \ln$ (Labor Composition) & 316 & .48 & .43 & .52 & -2.8 & 4.4 \\
$\Delta \ln$ (Labor Quantity) & 316 & 1.4 & 1.4 & 2.5 & -4.6 & 9.8 \\
$\Delta \ln$ (Employees) & 316 & 1.5 & 1.6 & 2.2 & -4.6 & 9.5 \\
$\Delta \ln$ (Hours Worked) & 283 & 1.3 & 1.3 & 2.5 & -4.6 & 9.8 \\
Exports \% GDP & 316 & 41 & 35 & 23 & 6.6 & 121 \\
ICT Compensation Share & 316 & .045 & .044 & .024 & .0014 & .12 \\
Non-ICT Compensation Share & 316 & .43 & .45 & .1 & .14 & .66 \\
Labor Compensation Share & 316 & .53 & .5 & .097 & .32 & .84 \\
\hline
\end{tabular}

Source: The Conference Board (2014a) and World Bank (2014), own calculations.

Table 3.4: Summary Statistics: Developed Countries - 1995-2010

\begin{tabular}{lcrrrrr}
\hline & N & Mean & Median & SD & Min & Max \\
\hline GDP per Capita & 297 & 38,044 & 37,098 & 6,575 & 23,913 & 58,957 \\
$\Delta \ln ($ GDP) & 297 & 2.4 & 2.6 & 2.3 & -5.8 & 11 \\
$\Delta \ln$ (ICT Cap. Serv) & 297 & 11 & 11 & 4.5 & .35 & 23 \\
$\Delta \ln$ (N.ICT Cap. Serv.) & 297 & 2.3 & 2.2 & 1.4 & -.45 & 8.1 \\
$\Delta \ln$ (Labor Serv.) & 297 & 1.3 & 1.4 & 1.8 & -5.7 & 6.5 \\
$\Delta \ln$ (Labor Composition) & 297 & .4 & .33 & .35 & -1.2 & 1.6 \\
$\Delta \ln$ (Labor Quantity) & 297 & .87 & .99 & 1.8 & -6.3 & 5.7 \\
$\Delta \ln$ (Employees) & 297 & 1.2 & 1.2 & 1.6 & -6.7 & 8.1 \\
$\Delta \ln$ (Hours Worked) & 297 & .87 & .99 & 1.8 & -6.3 & 5.7 \\
Exports \% GDP & 297 & 39 & 38 & 20 & 9.1 & 99.7 \\
ICT Compensation Share & 297 & .048 & .047 & .011 & .023 & .083 \\
Non-ICT Compensation Share & 297 & .32 & .31 & .058 & .2 & .52 \\
Labor Compensation Share & 297 & .63 & .64 & .056 & .44 & .75 \\
\hline
\end{tabular}

Source: The Conference Board (2014a) and World Bank (2014), own calculations. 
ICT capital $^{24}$ ranges in all countries groups between 4 and 5 percent, with the highest value in the developed economies. ${ }^{25}$ This is clearly an interesting result on its own. The within group variation in developing and emerging countries is much larger than in developed countries. The variation in time of the average ICT compensation share is displayed in Figure A.1 in the Appendix, showing for the emerging countries a slight upward trend and in contrast for the developed countries a minimal downward trend. ${ }^{26}$

\subsection{Econometric Model}

As shown in the descriptive statistics, the factor compensation shares of ICT capital in total factor compensation are nearly identical in developing, emerging and developed countries, with values ranging from 0.04 to 0.05 . Regression-based output elasticities are able to reveal whether there are excess return of investments in ICT capital and whether these returns are differing between the country subgroups. For the comparison of output elasticities between the three country groups, following e.g. Stiroh (2002), an (augmented) Cobb-Douglas production function without imposing constant returns to scale is estimated as follows:

$$
\Delta \ln Y_{c, t}=\beta_{I C T} \Delta \ln K_{c, t}^{I C T}+\beta_{N I C T} \Delta \ln K_{c, t}^{N I C T}+\beta_{L} \Delta \ln L_{c, t}+\beta_{X} \mathbf{X}_{\mathbf{c}, \mathbf{t}}+\lambda_{t}+\mu_{c}+\epsilon_{c, t}
$$

with $\Delta \ln Y_{c, t}$ being the growth rate of GDP and $\Delta \ln K_{c, t}^{I C T}, \Delta \ln K_{c, t}^{N I C T}, \Delta \ln L_{c, t}$ the growth rates of the input factors ICT capital services, non-ICT capital services and labor services in country $c$ at time $t . X$ denotes additional control variables in an augmented Cobb-Douglas production function setting controlling for differences in the production technology between countries. $\lambda_{t}$ are time dummies, whereas $\mu_{c}$ indicates country dummies (in the fixed effects setting). $\epsilon_{c, t}$ is the general error term. The time dummies control for common shocks arising for (almost) all countries such as the Global Financial Crisis of 2007-2008.

The econometric analysis is carried out for the full sample as well as for the subsamples of country groups. For the full sample regressions, I use four different estimators to estimate the Cobb-Douglas production function. The baseline specification is a pooled OLS (POLS) regression. In addition, I use a random effects (RE) estimator as well as a fixed-effects (FE) panel regressions model, where the latter controls for unmeasured cross-country differences. The fourth specification features a Panel-IV approach with lagged growth rates of ICT capital services. This controls, albeit not as perfectly as an external instrument, for the endogeneity of the ICT input variables. Due to the small number of observations, the IV approach is not feasible for the split-sample regressions.

If the 'leapfrogging' effect described by Steinmueller (2001) holds, the output elasticities of ICT in developing and emerging countries should be larger than those in developed countries. Another alternative would be the mean group (MG) estimator that allows for parameter heterogeneity between countries as described in Pesaran and Smith (1995). With this type of estimator, country specific estimations are carried out and later averaged across these countries. Given the still rather short time

\footnotetext{
${ }^{24}$ The country with the extraordinary low ICT capital compensation share is Iran in 1995.

${ }^{25}$ The two period averages of ICT and non-ICT capital compensation shares shown in Table in Tables 3.2, 3.3 and 3.4 are not directly available from the Total Economy Database and therefore calculated recursively: two period average ICT capital compensation $=$ GDP contribution of ICT $/ \Delta \ln$ ICT capital services.

${ }^{26}$ The non-ICT compensation share is very stable over time for all country subgroups as shown in A.2 in the Appendix.
} 
dimension in this empirical application, this estimator (and other heterogeneous parameter estimators) should be viable in future research with data sets of larger time dimension. ${ }^{27}$

\section{Empirical Results}

Table 4.1 presents the results for the Cobb-Douglas production function estimation of the full sample for the period 1995-2010. The growth rate of ICT capital services shows, with coefficients between 0.087 to 0.088 , a nearly identical output elasticity for the pooled OLS (column 1), the random effects (column 2) and the fixed effects specification (column 3). ${ }^{28}$ This estimated elasticity is larger than the ICT capital compensation share of 0.045 percent $^{29}$ and might be an indication of unmeasured complementarities or spillovers of ICT capital. The fourth column shows a fixed effects IV regression, where ICT, the main variable of interest, is instrumented by its lagged value. The ICT coefficient of 0.049 indicates that there might be an upward endogeneity bias in specifications (1) to (3) of Table 4.1. The estimated coefficients for labor services, which is a combined measure of labor quantity and composition, range from 0.334 to 0.361 depending on the type of estimator. The coefficients of NonICT capital range from 0.217 to 0.354 with the smallest values for the fixed effects and IV estimator.

Table 4.2 shows the regression results for an augmented Cobb-Douglas production function. Here,

Table 4.1: Dependent Variable: $\Delta \ln ($ GDP) - 1995-2010 - Full Sample

\begin{tabular}{lcccc}
\hline & $(1)$ & $(2)$ & $(3)$ & $(4)$ \\
& POLS & $\mathrm{RE}$ & $\mathrm{FE}$ & $\mathrm{IV}$ \\
\hline$\Delta \ln ($ ICT Cap. Serv) & $0.087^{* * *}$ & $0.088^{* * *}$ & $0.087^{* * *}$ & $0.049^{* * *}$ \\
& $(0.015)$ & $(0.014)$ & $(0.017)$ & $(0.018)$ \\
$\Delta \ln$ (N.ICT Cap. Serv.) & $0.354^{* * *}$ & $0.311^{* * *}$ & $0.236^{* * *}$ & $0.217^{* * *}$ \\
& $(0.079)$ & $(0.064)$ & $(0.056)$ & $(0.065)$ \\
$\Delta \ln$ (Labor Serv.) & $0.361^{* * *}$ & $0.340^{* * *}$ & $0.334^{* * *}$ & $0.342^{* * *}$ \\
& $(0.054)$ & $(0.055)$ & $(0.061)$ & $(0.044)$ \\
Constant & $0.994^{* * *}$ & $1.147^{* * *}$ & $1.412^{* * *}$ & \\
& $(0.276)$ & $(0.240)$ & $(0.257)$ & \\
Year Dummies & Yes & Yes & Yes & Yes \\
\hline Adjusted $R^{2}$ & 0.502 & 0.511 & 0.408 & 0.373 \\
Observations & 893 & 893 & 893 & 815 \\
\hline Clustered standard errors in parentheses & $* \mathrm{p}<0.10, * * \mathrm{p}<0.05, * * * \mathrm{p}<0.01$ & &
\end{tabular}

the additional variable is the share of exports in total GDP as an indicator for the openness to trade of a country. This indicator controls for differences in the production technology between countries. With the export coefficients clearly positive and significant, openness to trade is correlated with higher GDP growth rates. The output elasticity of ICT capital services in this augmented production function setting is now larger than in Table 4.1 for all specifications. The largest differences occur in the FE and IV specification with ICT coefficients of 0.10 and 0.066. One explanation for this result could be that the export share is capturing otherwise unmeasured cross-country heterogeneity. The same applies to the output elasticity of non-ICT capital. The coefficients in the fixed effects and Panel-IV

\footnotetext{
${ }^{27}$ Eberhardt et al. (2013) provides an in depth review and empirical application of heterogeneous parameter estimators.

${ }^{28} \mathrm{~A}$ hausman style test, indicating whether the random or the fixed effects estimator is more appropriate, is not easily feasible in a setting with robust standard errors.

${ }^{29}$ See Table A.6 in the Appendix.
} 
specification with the augmented Cobb-Douglas production function are also clearly larger than in Table 4.1 with the simple Cobb-Douglas production function.

Comparing the contribution of ICT to growth in developing, emerging and developed countries is the

Table 4.2: Dependent Variable: $\Delta \ln ($ GDP) - 1995-2010 - Full Sample

\begin{tabular}{lcccc}
\hline & $(1)$ & $(2)$ & $(3)$ & $(4)$ \\
& POLS & $\mathrm{RE}$ & $\mathrm{FE}$ & $\mathrm{IV}$ \\
\hline$\Delta \ln ($ ICT Cap. Serv) & $0.089^{* * *}$ & $0.092^{* * *}$ & $0.100^{* * *}$ & $0.066^{* * *}$ \\
& $(0.014)$ & $(0.014)$ & $(0.018)$ & $(0.018)$ \\
$\Delta \ln ($ N.ICT Cap. Serv.) & $0.351^{* * *}$ & $0.312^{* * *}$ & $0.283^{* * *}$ & $0.256^{* * *}$ \\
& $(0.082)$ & $(0.064)$ & $(0.051)$ & $(0.064)$ \\
$\Delta \ln ($ Labor Serv.) & $0.368^{* * *}$ & $0.341^{* * *}$ & $0.313^{* * *}$ & $0.323^{* * *}$ \\
& $(0.055)$ & $(0.055)$ & $(0.059)$ & $(0.043)$ \\
Exports \% GDP & $0.012^{*}$ & $0.019^{* * *}$ & $0.069^{* * *}$ & $0.073^{* * *}$ \\
& $(0.006)$ & $(0.006)$ & $(0.015)$ & $(0.015)$ \\
Constant & 0.469 & 0.344 & $-1.642^{* *}$ & $(0.672)$ \\
& $(0.348)$ & $(0.307)$ & Yes & Yes \\
Year Dummies & Yes & Yes & 0.426 & 0.398 \\
\hline Adjusted $R^{2}$ & 0.508 & 0.516 & & 815 \\
Observations & 893 & 893 &
\end{tabular}

main goal of the paper. Therefore, the production functions are estimated for each country subgroup individually in the next step. Table 4.3 presents results for the split sample regressions of the three country subgroups for the period 1995-2010. The coefficients for ICT show rather modest differences between the country subgroups. The ICT output elasticity of the fixed effects specification shows the same coefficients of 0.048 for both the developed and emerging countries. The contribution of ICT is slightly larger in developing countries with a coefficient of 0.077 . The estimated ICT coefficients are equal (for the developed countries) or larger (for the emerging and developing countries) than the ICT factor compensation shares shown in Tables 3.2, 3.3 and 3.4. However, a test of the equality of the fixed effects ICT coefficients across the three country subgroups could not be rejected. ${ }^{30}$ In other words, although the coefficient of ICT, with 0.077 in developing countries is larger than in developed and emerging countries, there is no statistically significant difference between the country subgroups. So even with this slightly higher point estimate, there is no clear evidence of the 'leapfrogging' through ICT hypothesis described in Steinmueller (2001). As a remark, the coefficients for non-ICT capital services in developed countries and labor services in developing countries are insignificant. This could be an indicator for measurement error. The fact that labor services in developing countries are mainly based on the number of employees and not on the preferable measure total hours worked could also be part of the explanation for the insignificant coefficients.

Table 4.4 shows the results for the country subgroups of the same robustness check as for the full sample specification in Table 4.2 before. The standard Cobb-Douglas production function for the three country subgroups is again augmented by the export share in GDP. The export share in emerging

\footnotetext{
${ }^{30}$ The test on the differences of the ICT coefficients between the country subgroups is conducted as follows: (1) estimate the OLS regression with country dummies, (2) estimate a seemingly unrelated regression and (3) test whether the difference between the coefficients of the country pairs is zero. All tests of the country pairs do no reject the differences between the ICT coefficients being zero.
} 
countries is, as in the full sample, positively correlated with GDP growth, whereas for developing and developed countries, only the FE specifications show significant effects. The fixed effects specifications (columns 3, 6 and 9) show slightly larger coefficients than before, ranging from 0.049 in developed countries to 0.103 in developing countries.

Tables A.1 and A.2 in the Appendix present results for a split into the subperiods 1995 to 2000 and 2000 to 2010 and reveal a lower ICT coefficient in the earlier period. These results seems to be largely driven by the emerging countries between 1995 and 2000, which display insignificant coefficients for this subperiod. ${ }^{31}$ However, during the subperiod 2000 to 2010, the ICT coefficients in emerging countries are slightly larger than in developing and developed countries. These substantial productivity gains of ICT capital in emerging countries still cannot provide statistically significant evidence for the 'leapfrogging' hypothesis.

${ }^{31}$ See Tables A.3 and A.4. 


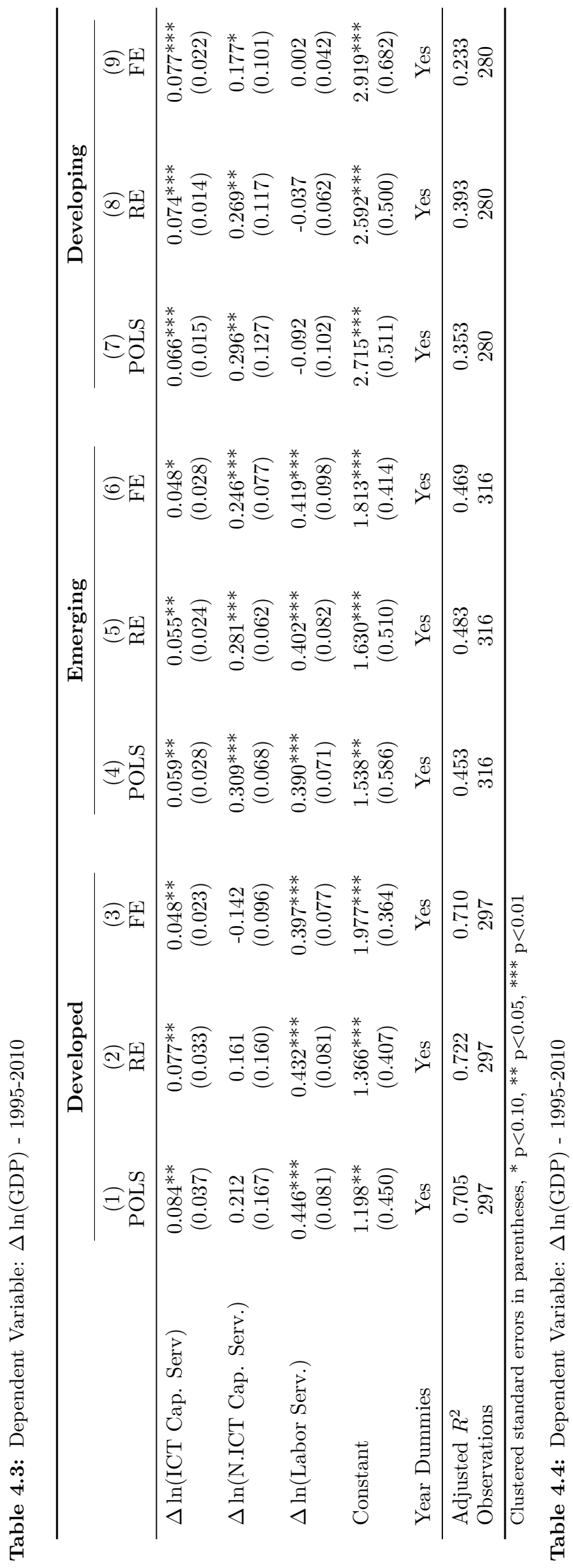

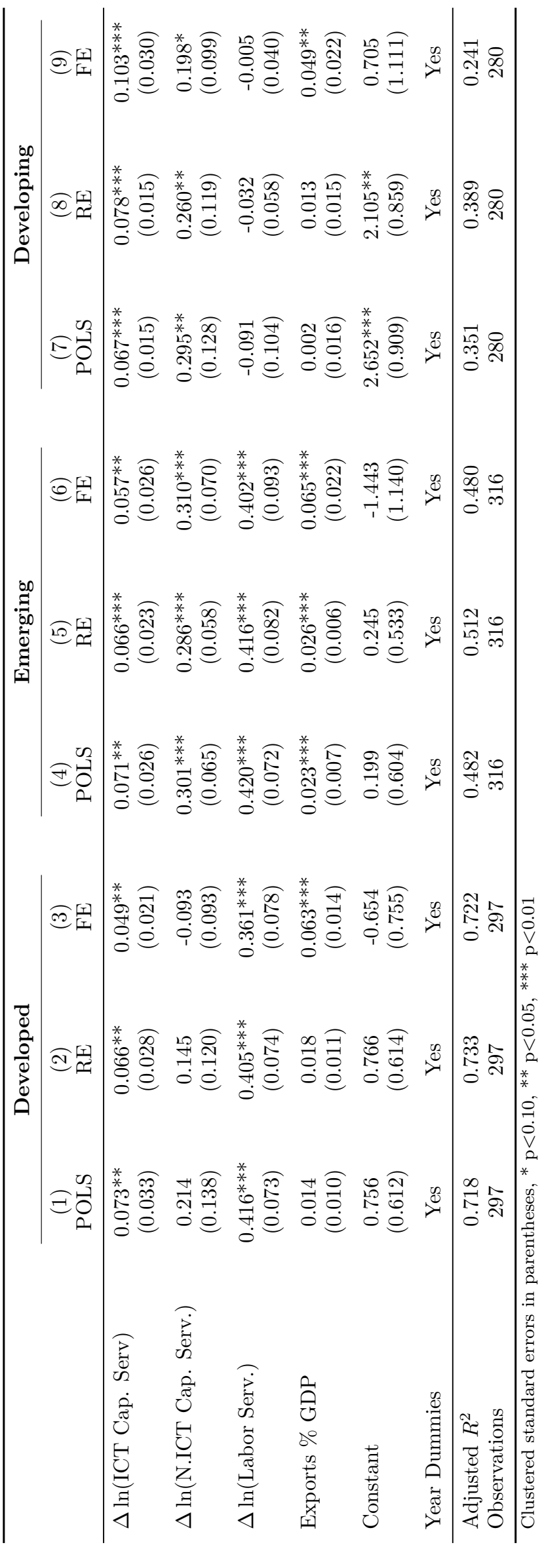




\section{Conclusion}

This paper investigates the importance of ICT for economic growth based on a sample of 59 countries over the period 1995 to 2010. The main question is whether the gains from investments in ICT are different between developing, emerging and developed countries. The regression of the full sample of countries reveals an output elasticity of ICT that is larger than the ICT factor compensation share indicating possible spillovers and complementarities of investments in ICT.

The regressions for the three country subsamples reveal rather small differences in the output elasticities of ICT between developing, emerging and developed countries. These output elasticities are, except for the developed countries, larger than the ICT capital compensation shares, whereas the ICT capital compensation shares are nearly identical in the three country subgroups and rather stable over time. A test on the equality of estimated coefficients could not be rejected, despite the coefficients being somewhat larger for the developing and emerging countries. There is no clear statistical indication that developing and emerging countries are gaining more from investments in ICT than developed economies. Therefore, the macroeconometric validity of the 'leapfrogging' through ICT argument as pointed out by Steinmueller (2001) remains questionable.

Two additional issues are worth mentioning. While the present data set covers the majority of developed countries, emerging and developing countries are only represented to a certain extent. The list of developing and emerging countries with data on ICT capital input might not be randomly defined, but rather represents countries with larger GDP growth during the sample period. Therefore, a selection bias into the direction of countries that use ICT more efficiently might be present, resulting in the generalizability of the results being only valid to a certain extent. Furthermore, not only economic but also political and societal aspects such as the simplified access to information should be taken into account when investigating the impact of ICT in developing and emerging countries.

Additional analysis, based on larger sample sizes with respect to time as well as to the number of countries per subgroup, should be able to use more refined econometric methods, helping to confirm the current results. This is especially important with regard to the potential endogeneity issues within macro-level production function estimations. Furthermore, complementary firm-level studies could help to gain deeper insights into the productivity effects of ICT in developing and emerging countries. 


\section{A Appendix}

\section{A.1 Additional Graphs}

Figure A.1: Average ICT Capital Compensation Share

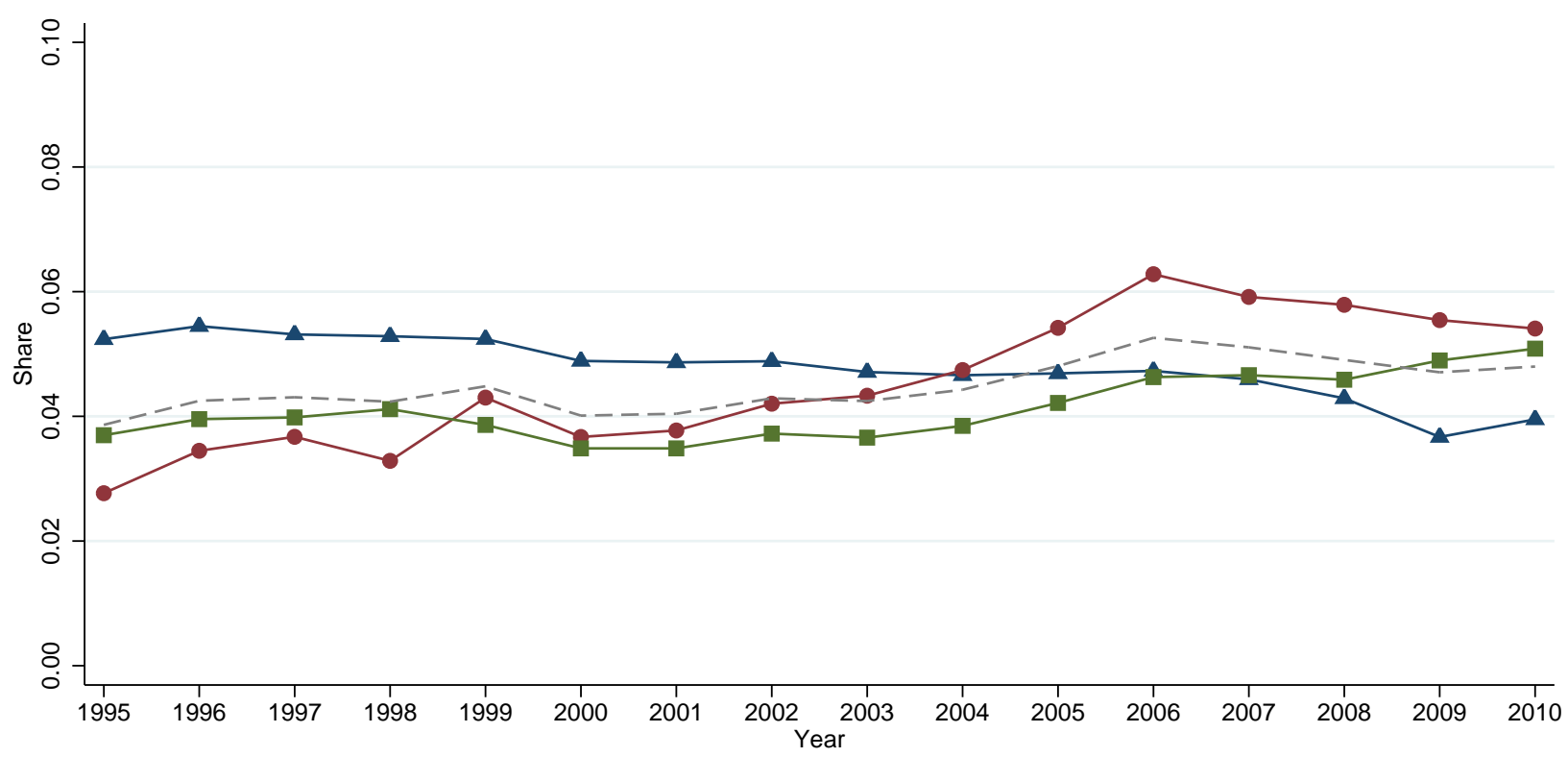

$\longrightarrow$ Developed $\longrightarrow$ Emerging Developing $\longrightarrow----$ Total

Source: The Conference Board (2014a).

Figure A.2: Average Non-ICT Capital Compensation Share

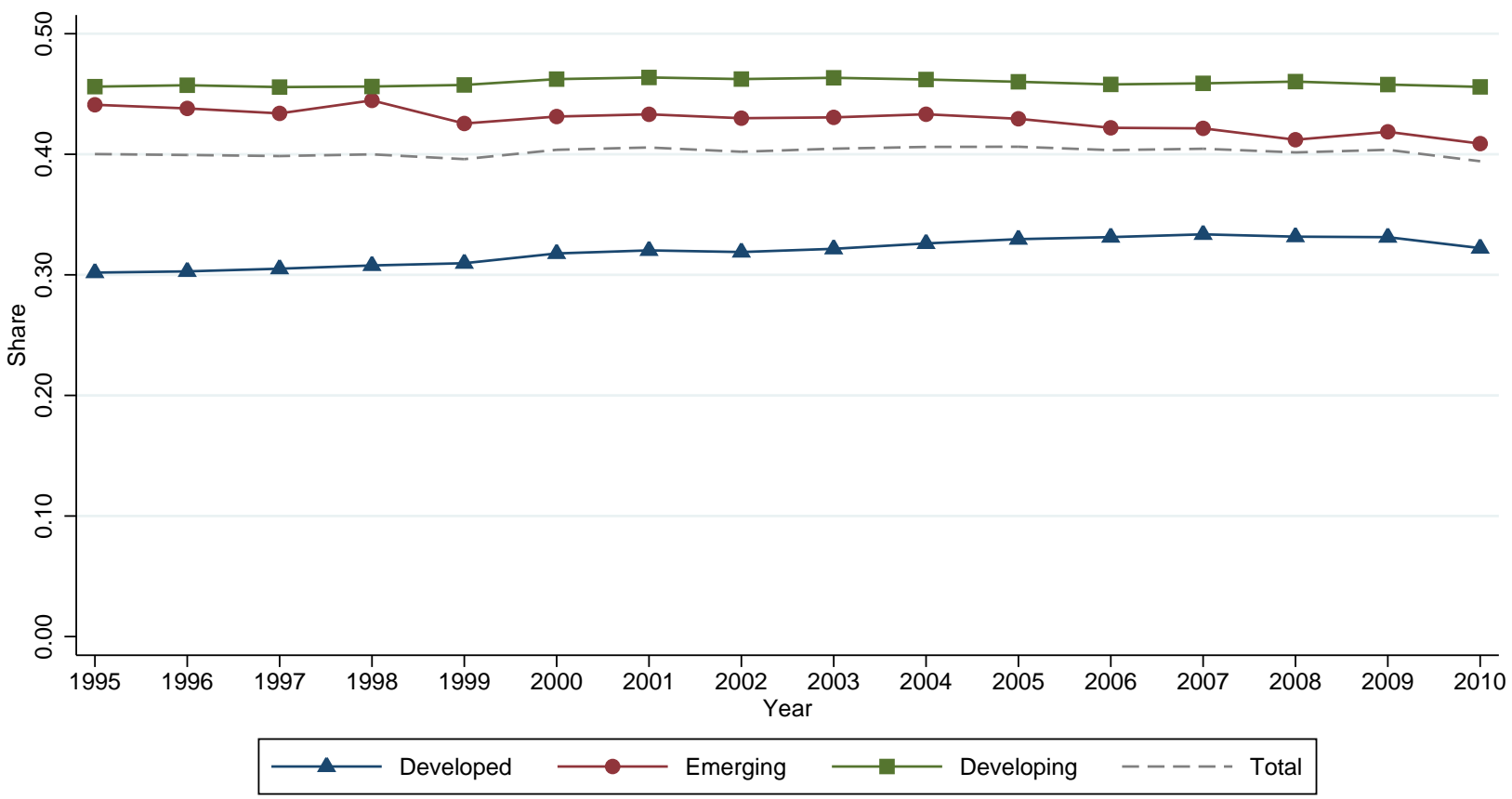

Source: The Conference Board (2014a). 
Figure A.3: GDP Growth vs ICT Capital Services Growth - Average of 1995-2010
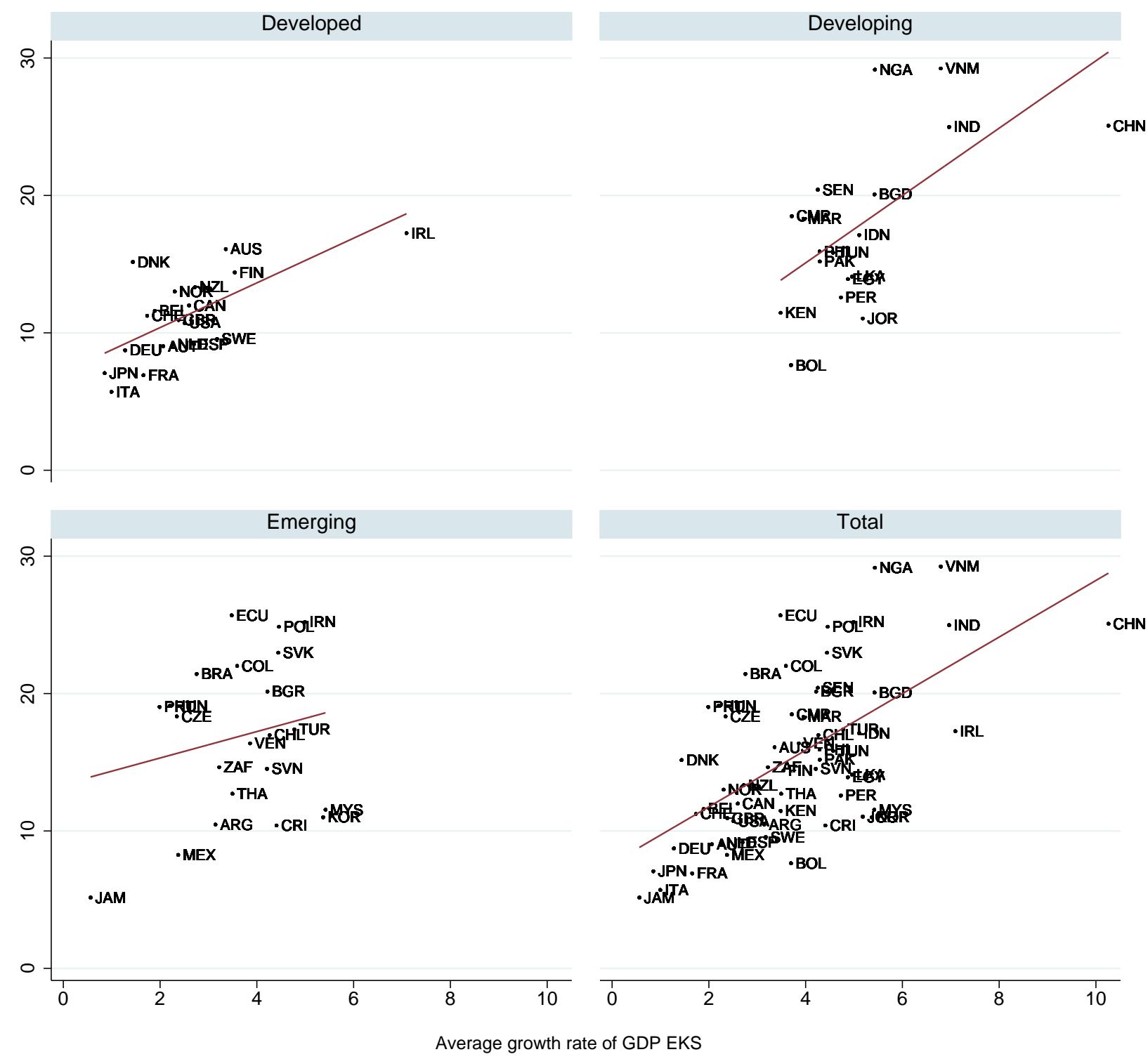

Average growth rate of GDP EKS

- Average growth rate of ICT capital services —— Fitted values

Note: Developed > 23000 of 2013 US\$ GDP per Capita, Developing <6500 of 2013 US \$ GDP per Capita in Year 1995

Source: The Conference Board (2014a). 


\section{A.2 Additional Tables}

Table A.1: Dependent Variable: $\Delta \ln ($ GDP $)$ - 1995-2000 - Full Sample

\begin{tabular}{|c|c|c|c|}
\hline & $\begin{array}{c}(1) \\
\text { POLS }\end{array}$ & $\begin{array}{l}(2) \\
\mathrm{RE}\end{array}$ & $\begin{array}{l}(3) \\
\text { FE }\end{array}$ \\
\hline$\Delta \ln ($ ICT Cap. Serv $)$ & $\begin{array}{c}0.063^{* *} \\
(0.024)\end{array}$ & $\begin{array}{c}0.065^{* * *} \\
(0.024)\end{array}$ & $\begin{array}{l}0.072^{*} \\
(0.043)\end{array}$ \\
\hline$\Delta \ln ($ N.ICT Cap. Serv.) & $\begin{array}{c}0.334^{* * *} \\
(0.059)\end{array}$ & $\begin{array}{c}0.317^{* * *} \\
(0.058)\end{array}$ & $\begin{array}{c}0.218^{* *} \\
(0.090)\end{array}$ \\
\hline$\Delta \ln ($ Labor Serv. $)$ & $\begin{array}{c}0.402^{* * *} \\
(0.085)\end{array}$ & $\begin{array}{c}0.380^{* * * *} \\
(0.087)\end{array}$ & $\begin{array}{c}0.317^{* * * *} \\
(0.107)\end{array}$ \\
\hline Exports \% GDP & $\begin{array}{c}0.019^{*} \\
(0.010)\end{array}$ & $\begin{array}{c}0.020^{* *} \\
(0.010)\end{array}$ & $\begin{array}{c}0.052 \\
(0.036)\end{array}$ \\
\hline Constant & $\begin{array}{c}0.538 \\
(0.609)\end{array}$ & $\begin{array}{c}0.539 \\
(0.584)\end{array}$ & $\begin{array}{l}-0.365 \\
(1.597)\end{array}$ \\
\hline Year Dummies & Yes & Yes & Yes \\
\hline $\begin{array}{l}\text { Adjusted } R^{2} \\
\text { Observations }\end{array}$ & $\begin{array}{c}0.328 \\
335\end{array}$ & $\begin{array}{c}0.345 \\
335\end{array}$ & $\begin{array}{c}0.139 \\
335\end{array}$ \\
\hline
\end{tabular}

Table A.2: Dependent Variable: $\Delta \ln ($ GDP $)$ - 2000-2010 - Full Sample

\begin{tabular}{|c|c|c|c|}
\hline & $\begin{array}{c}(1) \\
\text { POLS }\end{array}$ & $\begin{array}{l}(2) \\
\mathrm{RE}\end{array}$ & $\begin{array}{l}(3) \\
\mathrm{FE}\end{array}$ \\
\hline$\Delta \ln ($ ICT Cap. Serv) & $\begin{array}{c}0.105^{* * *} \\
(0.015)\end{array}$ & $\begin{array}{c}0.096 * * * \\
(0.015)\end{array}$ & $\begin{array}{c}0.099 * * * \\
(0.020)\end{array}$ \\
\hline$\Delta \ln ($ N.ICT Cap. Serv.) & $\begin{array}{c}0.363^{* * *} \\
(0.110)\end{array}$ & $\begin{array}{c}0.352^{* * *} \\
(0.072)\end{array}$ & $\begin{array}{c}0.342^{* * *} \\
(0.066)\end{array}$ \\
\hline$\Delta \ln ($ Labor Serv. $)$ & $\begin{array}{c}0.312^{* * *} \\
(0.063)\end{array}$ & $\begin{array}{c}0.275^{* * *} \\
(0.050)\end{array}$ & $\begin{array}{c}0.252^{* * *} \\
(0.052)\end{array}$ \\
\hline Exports \% GDP & $\begin{array}{l}0.011^{*} \\
(0.006)\end{array}$ & $\begin{array}{c}0.021^{* * *} \\
(0.007)\end{array}$ & $\begin{array}{c}0.078 * * * \\
(0.020)\end{array}$ \\
\hline Constant & $\begin{array}{c}0.332 \\
(0.357)\end{array}$ & $\begin{array}{c}0.156 \\
(0.327)\end{array}$ & $\begin{array}{c}-2.107^{* *} \\
(0.856)\end{array}$ \\
\hline Year Dummies & Yes & Yes & Yes \\
\hline $\begin{array}{l}\text { Adjusted } R^{2} \\
\text { Observations }\end{array}$ & $\begin{array}{c}0.590 \\
616\end{array}$ & $\begin{array}{c}0.592 \\
616\end{array}$ & $\begin{array}{c}0.539 \\
616\end{array}$ \\
\hline
\end{tabular}

Clustered standard errors in parentheses, ${ }^{*} \mathrm{p}<0.10,{ }^{* *} \mathrm{p}<0.05,{ }^{* * *} \mathrm{p}<0.01$ 


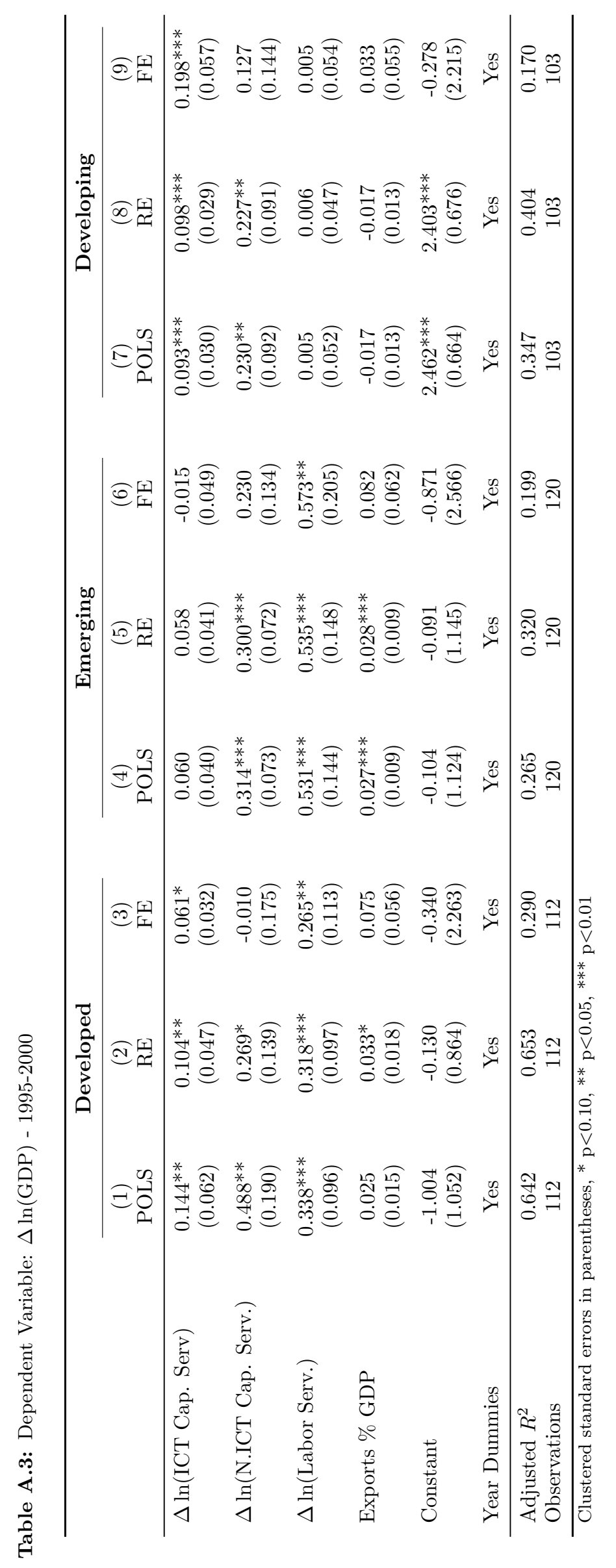




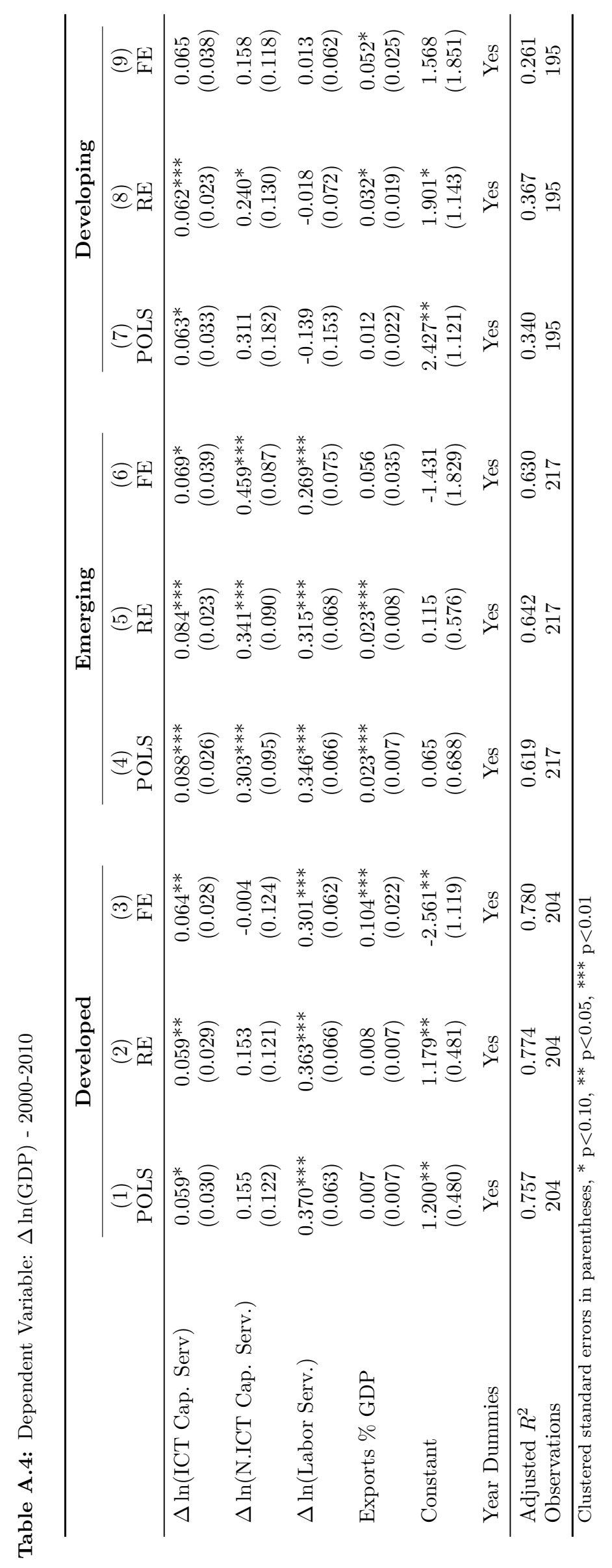


Table A.5: Factor Compensation Shares: Country Groups - 1995-2010

\begin{tabular}{|c|c|c|c|c|c|c|c|c|}
\hline & \multicolumn{2}{|c|}{ Developed } & \multicolumn{2}{|c|}{ Emerging } & \multicolumn{2}{|c|}{ Developing } & \multicolumn{2}{|c|}{ Total } \\
\hline & $\mathrm{N}$ & Mean & $\mathrm{N}$ & Mean & $\mathrm{N}$ & Mean & $\mathrm{N}$ & Mean \\
\hline ICT Compensation Share & 297 & .048 & 316 & .045 & 280 & .041 & 893 & .045 \\
\hline Non-ICT Compensation Share & 297 & .32 & 316 & .43 & 280 & .46 & 893 & .4 \\
\hline Labor Compensation Share & 297 & .63 & 316 & .53 & 280 & .5 & 893 & .55 \\
\hline
\end{tabular}

Source: The Conference Board (2014a).

Table A.6: Summary Statistics: 1995-2010 - Full Sample

\begin{tabular}{|c|c|c|c|c|c|c|}
\hline & $\mathrm{N}$ & Mean & Median & $\mathrm{SD}$ & Min & $\operatorname{Max}$ \\
\hline GDP per Capita & 893 & 18,426 & 11,818 & 15,377 & 998 & 58,957 \\
\hline$\Delta \ln (\mathrm{GDP})$ & 893 & 3.7 & 3.8 & 2.8 & -8 & 14 \\
\hline$\Delta \ln (\mathrm{ICT}$ Cap. Serv $)$ & 893 & 15 & 14 & 7.4 & -.46 & 44 \\
\hline$\Delta \ln ($ N.ICT Cap. Serv.) & 893 & 3.6 & 2.9 & 2.6 & -1.2 & 13 \\
\hline$\Delta \ln$ (Labor Serv.) & 893 & 2 & 2 & 2.2 & -5.7 & 10 \\
\hline$\Delta \ln ($ Labor Composition) & 893 & .38 & .32 & .39 & -2.8 & 4.4 \\
\hline$\Delta \ln$ (Labor Quantity) & 893 & 1.6 & 1.6 & 2.2 & -6.3 & 10 \\
\hline$\Delta \ln ($ Employees $)$ & 893 & 1.7 & 1.7 & 1.9 & -6.7 & 9.5 \\
\hline$\Delta \ln ($ Hours Worked $)$ & 626 & 1.2 & 1.2 & 2.2 & -6.3 & 10 \\
\hline Exports \% GDP & 893 & 37 & 32 & 20 & 6.6 & 121 \\
\hline ICT Compensation Share & 893 & .045 & .044 & .02 & .0014 & .12 \\
\hline Non-ICT Compensation Share & 893 & .4 & .43 & .092 & .14 & .66 \\
\hline Labor Compensation Share & 893 & .55 & .5 & .088 & .32 & .84 \\
\hline
\end{tabular}

Source: The Conference Board (2014a) and World Bank (2014), own calculations. 
Table A.7: List of Dropped Observations

\begin{tabular}{|c|c|c|c|c|c|c|c|c|c|c|}
\hline Country & Year & GDPg & LABg & ICTg & NICTg & ICT Comp. & Error & Scatter & DFBETA & Hadi \\
\hline ARG & 1995 & -2.93 & -10.02 & 7.66 & 2.92 & 0.044 & 0 & 0 & 0 & 1 \\
\hline ARG & 1997 & 7.45 & 11.84 & 7.66 & 3.16 & 0.040 & 0 & 0 & 0 & 1 \\
\hline ARG & 2002 & -11.43 & -13.09 & 1.58 & -0.99 & 0.013 & 0 & 0 & 0 & 1 \\
\hline ARG & 2003 & 7.60 & 16.43 & 0.38 & -2.12 & 0.000 & 1 & 0 & 0 & 1 \\
\hline ARG & 2004 & 7.04 & 14.27 & 4.94 & 1.09 & 0.049 & 0 & 0 & 0 & 1 \\
\hline ARG & 2009 & -3.28 & -3.59 & 15.78 & 3.59 & 0.000 & 1 & 0 & 0 & 0 \\
\hline ARG & 2010 & 8.00 & 5.48 & 13.59 & 3.65 & 0.000 & 1 & 0 & 0 & 0 \\
\hline BGR & 1996 & -9.46 & 3.09 & 14.07 & 2.11 & 0.048 & 0 & 0 & 0 & 1 \\
\hline BGR & 2009 & -5.63 & -3.79 & 20.07 & 10.14 & 0.068 & 0 & 0 & 0 & 1 \\
\hline BRA & 2010 & 6.64 & 4.44 & 15.52 & 3.72 & 0.000 & 1 & 0 & 0 & 0 \\
\hline $\mathrm{CHN}$ & 1996 & 2.04 & 1.41 & 34.86 & 10.55 & 0.028 & 0 & 0 & 1 & 0 \\
\hline $\mathrm{CHN}$ & 1998 & 0.29 & 1.56 & 28.49 & 9.23 & 0.036 & 0 & 0 & 1 & 0 \\
\hline COL & 1999 & -4.29 & -1.56 & 32.35 & 1.52 & 0.019 & 0 & 1 & 0 & 0 \\
\hline CZE & 2004 & 4.63 & 0.98 & 3.49 & 4.98 & 0.042 & 0 & 1 & 0 & 0 \\
\hline CZE & 2005 & 6.53 & 2.59 & 2.63 & 5.15 & 0.037 & 0 & 1 & 0 & 0 \\
\hline CZE & 2006 & 6.78 & 0.56 & 3.07 & 5.40 & 0.035 & 0 & 1 & 0 & 0 \\
\hline ECU & 1999 & -4.86 & -2.04 & 28.58 & 0.51 & 0.011 & 0 & 1 & 0 & 0 \\
\hline FIN & 1995 & 3.89 & 2.52 & 24.28 & -2.51 & 0.029 & 0 & 1 & 0 & 0 \\
\hline FIN & 1996 & 3.51 & 1.78 & 22.65 & -0.96 & 0.035 & 0 & 1 & 0 & 0 \\
\hline FIN & 2009 & -8.93 & -3.30 & 11.36 & 1.40 & 0.079 & 0 & 0 & 1 & 0 \\
\hline IDN & 1998 & -14.08 & 1.07 & 3.71 & 6.86 & 0.021 & 0 & 1 & 0 & 1 \\
\hline IRL & 2008 & -2.18 & -1.47 & 14.60 & 5.56 & 0.050 & 0 & 0 & 1 & 0 \\
\hline IRL & 2009 & -6.60 & -9.63 & 11.94 & 4.33 & 0.045 & 0 & 0 & 1 & 1 \\
\hline IRL & 2010 & -1.07 & -4.47 & 10.36 & 2.73 & 0.042 & 0 & 0 & 1 & 0 \\
\hline KOR & 1998 & -5.87 & -7.38 & 12.73 & 4.98 & 0.057 & 0 & 0 & 0 & 1 \\
\hline LKA & 2009 & 3.48 & 0.30 & 31.47 & 3.89 & 0.189 & 1 & 0 & 0 & 0 \\
\hline LKA & 2010 & 7.71 & 3.33 & 29.66 & 3.70 & 0.341 & 1 & 0 & 0 & 0 \\
\hline MAR & 1995 & -6.81 & 4.08 & 10.62 & 0.55 & 0.046 & 0 & 0 & 1 & 0 \\
\hline MAR & 1996 & 11.53 & 3.06 & 11.24 & 0.83 & 0.047 & 0 & 0 & 1 & 0 \\
\hline MYS & 1995 & 9.38 & 5.82 & 11.76 & 13.92 & 0.128 & 0 & 0 & 0 & 1 \\
\hline MYS & 1998 & -7.64 & 0.59 & 10.65 & 6.67 & 0.123 & 0 & 0 & 0 & 1 \\
\hline NGA & 2002 & 19.35 & 3.48 & 30.79 & 2.09 & 0.021 & 0 & 1 & 0 & 1 \\
\hline POL & 1999 & 4.42 & -4.36 & 40.88 & 4.84 & 0.017 & 0 & 0 & 0 & 1 \\
\hline SVN & 2009 & -8.28 & -7.67 & 11.96 & 3.41 & 0.052 & 0 & 0 & 0 & 1 \\
\hline SWE & 2009 & -5.16 & -2.80 & 8.60 & 2.00 & 0.056 & 0 & 0 & 1 & 0 \\
\hline TUR & 2008 & 0.66 & 1.82 & 21.09 & 6.55 & 0.000 & 1 & 0 & 0 & 0 \\
\hline TUR & 2009 & -4.95 & -0.39 & 16.05 & 4.93 & 0.000 & 1 & 0 & 0 & 0 \\
\hline TUR & 2010 & 8.62 & 6.02 & 13.35 & 4.80 & 0.000 & 1 & 0 & 0 & 0 \\
\hline VEN & 2002 & -9.27 & 0.71 & 11.86 & 0.25 & 0.023 & 0 & 1 & 0 & 1 \\
\hline VEN & 2003 & -8.07 & 0.99 & 8.54 & -1.95 & 0.035 & 0 & 1 & 0 & 0 \\
\hline VEN & 2004 & 16.79 & 6.88 & 11.06 & -2.33 & 0.052 & 0 & 0 & 0 & 1 \\
\hline VEN & 2008 & 5.14 & 4.57 & 24.99 & 4.80 & 0.002 & 1 & 0 & 0 & 0 \\
\hline VEN & 2009 & -3.25 & 2.74 & 20.12 & 4.05 & 0.002 & 1 & 0 & 0 & 0 \\
\hline VEN & 2010 & -1.50 & 2.71 & 15.37 & 3.39 & 0.002 & 1 & 0 & 0 & 0 \\
\hline
\end{tabular}

Source: The Conference Board (2014a). 
Table A.8: GDP per capita in 2013 US\$ in Year 2010

\begin{tabular}{|c|c|c|c|c|c|c|c|c|c|c|c|}
\hline \multicolumn{4}{|c|}{ Developed } & \multicolumn{4}{|c|}{ Emerging } & \multicolumn{4}{|c|}{ Developing } \\
\hline 1. & Norway & NOR & 57,706 & 1. & South Korea & KOR & 31,319 & 1. & Peru & PER & 9,009 \\
\hline 2. & United States & USA & 50,605 & 2. & Slovenia & SVN & 29,384 & 2. & China & $\mathrm{CHN}$ & 8,910 \\
\hline 3. & Switzerland & CHE & 48,002 & 3. & Czech Republic & $\mathrm{CZE}$ & 27,287 & 3. & Tunisia & TUN & 8,173 \\
\hline 4. & Australia & AUS & 45,814 & 4. & Portugal & PRT & 23,535 & 4. & Jordan & JOR & 5,623 \\
\hline 5. & Austria & AUT & 44,021 & 5. & Slovak Republic & SVK & 22,576 & 5. & Egypt & EGY & 5,516 \\
\hline 6. & Netherlands & NLD & 43,977 & 6. & Poland & POL & 19,629 & 6. & Indonesia & IDN & 4,921 \\
\hline 7. & Sweden & SWE & 43,236 & 7. & Hungary & HUN & 19,054 & 7. & Sri Lanka & LKA & 4,870 \\
\hline 8. & Canada & CAN & 42,855 & 8. & Chile & CHL & 15,284 & 8. & Bolivia & BOL & 4,517 \\
\hline 9. & Belgium & BEL & 41,118 & 9. & Malaysia & MYS & 14,989 & 9. & Morocco & MAR & 4,089 \\
\hline 10. & United Kingdom & GBR & 39,545 & 10. & Mexico & MEX & 14,185 & 10. & Philippines & PHL & 3,817 \\
\hline 11. & Denmark & DNK & 39,299 & 11. & Argentina & ARG & 13,787 & 11. & India & IND & 3,764 \\
\hline 12. & Germany & $\mathrm{DEU}$ & 38,892 & 12. & Iran & IRN & 13,448 & 12. & Vietnam & VNM & 3,691 \\
\hline 13. & Ireland & IRL & 38,869 & 13. & Costa Rica & CRI & 13,388 & 13. & Pakistan & PAK & 2,800 \\
\hline 14. & Finland & FIN & 38,007 & 14. & Bulgaria & BGR & 12,622 & 14. & Cameroon & CMR & 2,136 \\
\hline 15. & Japan & JPN & 36,765 & 15. & Turkey & TUR & 12,241 & 15. & Nigeria & NGA & 2,098 \\
\hline 16. & France & FRA & 35,606 & 16. & Venezuela & VEN & 11,147 & 16. & Bangladesh & BGD & 1,762 \\
\hline 17. & Italy & ITA & 32,664 & 17. & Thailand & THA & 10,220 & 17. & Senegal & SEN & 1,620 \\
\hline 18. & New Zealand & NZL & 31,949 & 18. & Brazil & BRA & 9,958 & 18. & Kenya & KEN & 1,442 \\
\hline \multirow[t]{4}{*}{19.} & Spain & ESP & 31,669 & 19. & Jamaica & JAM & 9,893 & & & & \\
\hline & & & & 20. & Colombia & $\mathrm{COL}$ & 9,181 & & & & \\
\hline & & & & 21. & South Africa & $\mathrm{ZAF}$ & 9,103 & & & & \\
\hline & & & & 22. & Ecuador & $\mathrm{ECU}$ & 8,051 & & & & \\
\hline
\end{tabular}




\section{References}

Aker, J. C. and I. M. Mbiti (2010). "Mobile Phones and Economic Development in Africa". The Journal of Economic Perspectives 24(3), pp. 207-232.

Ardizzi, G., C. Petraglia, M. Piacenza, and G. Turati (2014). "Measuring the Underground Economy with the Currency Demand Approach: A Reinterpretation of the Methodology, With an Application to Italy". Review of Income and Wealth 60(4), pp. 747-772.

Arellano, M. and S. Bond (1991). "Some Tests of Specification for Panel Data: Monte Carlo Evidence and an Application to Employment Equations". The Review of Economic Studies 58(2), pp. 277297.

Biagi, F. (2013). ICT and Productivity: A Review of the Literature. JRC-IPTS Working Papers on Digital Economy 2013-09. Institute of Prospective Technological Studies, Joint Research Centre.

Cardona, M., T. Kretschmer, and T. Strobel (2013). "ICT and Productivity: Conclusions from the Empirical Literature". Information Economics and Policy 25(3), pp. 109-125.

Commander, S., R. Harrison, and N. Menezes-Filho (2011). "ICT and Productivity in Developing Countries: New Firm-Level Evidence from Brazil and India". Review of Economics and Statistics 93(2), pp. 528-541.

Czernich, N., O. Falck, T. Kretschmer, and L. Woessmann (2011). "Broadband Infrastructure and Economic Growth". The Economic Journal 121(552), pp. 505-532.

Dahl, C., H. Kongsted, and A. Sørensen (2011). "ICT and Productivity Growth in the 1990s: Panel Data Evidence on Europe". Empirical Economics 40(1), pp. 141-164.

Dedrick, J., K. L. Kraemer, and E. Shih (2013). "Information Technology and Productivity in Developed and Developing Countries." Journal of Management Information Systems 30(1), pp. 97122 .

Dewan, S. and K. L. Kraemer (2000). "Information Technology and Productivity: Evidence from Country-Level Data". Management Science 46(4), pp. 548-562.

Dimelis, S. and S. Papaioannou (2010). "FDI and ICT Effects on Productivity Growth: A Comparative Analysis of Developing and Developed Countries". European Journal of Development Research 22(1), pp. 79-96.

- (2011). "ICT Growth Effects at the Industry Level: A Comparison Between the US and the EU". Information Economics and Policy 23(1), pp. 37-50.

Draca, M., R. Sadun, and J. Van Reenen (2007). "Productivity and ICT: A Review of the Evidence". The Oxford Handbook of Information and Communication Technologies. Ed. by R. Mansell. Oxford University Press, pp. 100-147.

Durham, J. (2004). "Absorptive Capacity and the Effects of Foreign Direct Investment and Equity Foreign Portfolio Investment on Economic Growth". European Economic Review 48(2), pp. 285306.

Eberhardt, M., C. Helmers, and H. Strauss (2013). "Do Spillovers Matter when Estimating Private Returns to R\&D?" Review of Economics and Statistics 95(2), pp. 436-448.

Hadi, A. S. (1992). "Identifying Multiple Outliers in Multivariate Data". Journal of the Royal Statistical Society. Series B (Methodological), pp. 761-771. 
Hadi, A. S. (1994). "A Modification of a Method for the Detection of Outliers in Multivariate Samples". Journal of the Royal Statistical Society. Series B (Methodological), pp. 393-396.

Hansen, B. E. (2000). "Sample Splitting and Threshold Estimation". Econometrica 68(3), pp. 575604.

Harbaugh, W. T., A. Levinson, and D. M. Wilson (2002). "Reexamining the Empirical Evidence for an Environmental Kuznets Curve". Review of Economics and Statistics 84(3), pp. 541-551.

Henry, M., R. Kneller, and C. Milner (2009). "Trade, Technology Transfer and National Efficiency in Developing Countries". European Economic Review 53(2), pp. 237-254.

Inklaar, R., M. O'Mahony, and M. P. Timmer (2005). "ICT and Europe's Productivity Performance: Industry-Level Growth Account Comparisons with the United States". Review of Income and Wealth 51(4), pp. 505-536.

Inklaar, R. and M. P. Timmer (2013). Capital, Labor and TFP in PWT8.0. Available at http://www .rug.nl/research/ggdc/data/pwt/v80/capital_labor_and_tfp_in_pwt80.pdf.

Inklaar, R., M. P. Timmer, and B. Van Ark (2008). "Market Services Productivity Across Europe and the US". Economic Policy 23(53), pp. 139-194.

Jorgenson, D. W. and K. J. Stiroh (2000). "Raising the Speed Limit: U.S. Economic Growth in the Information Age". Brookings Papers on Economic Activity 31(1), pp. 125-236.

Jorgenson, D. W. and K. M. Vu (2005). "Information Technology and the World Economy". Scandinavian Journal of Economics 107(4), pp. 631-650.

- (2010). "Potential Growth of the World Economy". Journal of Policy Modeling 32(5), pp. 615-631.

- (2011). "The Rise of Developing Asia and the New Economic Order". Journal of Policy Modeling 33(5), pp. 698-716.

Keller, W. (1996). "Absorptive Capacity: On the Creation and Acquisition of Technology in Development". Journal of Development Economics 49(1), pp. 199-227.

- (2004). "International Technology Diffusion". Journal of Economic Literature 42(3), pp. 752-782.

Klasen, S. and D. Blades (2013). "Issues and Challenges in Measuring National Income, Wealth, Poverty, and Inequality in Sub-Saharan African Countries: An Introduction". Review of Income and Wealth 59, S1-S8.

Kneller, R. (2005). "Frontier Technology, Absorptive Capacity and Distance". Oxford Bulletin of Economics and Statistics 67(1), pp. 1-23.

Oliner, S. D. and D. E. Sichel (2000). "The Resurgence of Growth in the Late 1990s: Is Information Technology the Story?" Journal of Economic Perspectives 14(4), pp. 3-22.

- (2002). "Information Technology and Productivity: Where are we now and Where are we Going?" Economic Review Q3, pp. 15-44.

O'Mahony, M. and M. P. Timmer (2009). "Output, Input and Productivity Measures at the Industry Level: The EU KLEMS Database”. Economic Journal 119(538), F374-F403.

O'Mahony, M. and M. Vecchi (2005). "Quantifying the Impact of ICT Capital on Output Growth: A Heterogeneous Dynamic Panel Approach”. Economica 72(288), pp. 615-633.

Papaioannou, S. and S. Dimelis (2007). "Information Technology as a Factor of Economic Development: Evidence from Developed and Developing Countries". Economics of Innovation and New Technology 16(3), pp. 179-194. 
Pesaran, M. H. and R. Smith (1995). "Estimating Long-Run Relationships from Dynamic Heterogeneous Panels". Journal of Econometrics 68(1), pp. 79-113.

Pilat, D. (2004). "The ICT Productivity Paradox: Insights from Micro Data". OECD Economic Studies 2004(1), pp. 37-65.

Pohjola, M. (2002). "The New Economy in Growth and Development". Oxford Review of Economic Policy 18(3), pp. 380-396.

Roller, L.-H. and L. Waverman (2001). "Telecommunications Infrastructure and Economic Development: A Simultaneous Approach". American Economic Review 91(4), pp. 909-923.

Steinmueller, W. E. (2001). "ICTs and the Possibilities for Leapfrogging by Developing Countries". International Labour Review 140(2), pp. 193-210.

Stiroh, K. J. (2002). "Are ICT Spillovers Driving the New Economy?" Review of Income and Wealth 48(1), pp. 33-57.

- (2005). "Reassessing the Impact of IT in the Production Function: A Meta-Analysis and Sensitivity Tests". Annales d'Economie et de Statistique 79/80, pp. 529-561.

Strauss, H. and B. Samkharadze (2011). "ICT Capital and Productivity Growth". EIB Papers 16(2), pp. 8-28.

Temple, J. (2000). "Growth Regressions and What the Textbooks Don't Tell You". Bulletin of Economic Research 52(3), pp. 181-205.

The Conference Board (2014a). Total Economy Database ${ }^{\mathrm{TM}}$, January 2014. http://www. conferenc e-board.org/data/economydatabase/.

- (2014b). Total Economy Database ${ }^{\mathrm{TM}}$, January 2014 - Methodological Notes. Available at http: //www . conference-board.org/retrievefile.cfm?filename=TED-Methodological-Notes .pd f\&type=subsite.

Timmer, M. P., R. Inklaar, M. O’Mahony, and B. Van Ark (2010). Economic Growth in Europe: A Comparative Industry Perspective. Cambridge University Press.

- (2011). "Productivity and Economic Growth in Europe: A Comparative Industry Perspective". International Productivity Monitor 21, pp. 3-23.

United Nations (2011). Information Economy Report 2011: ICTs as an Enabler for Private Sector Development. United Nations Conference on Trade and Development. United Nations Publications.

Van Ark, B., M. O'Mahony, and M. P. Timmer (2008). "The Productivity Gap Between Europe and the United States: Trends and Causes". The Journal of Economic Perspectives 22(1), pp. 25-44.

Van Reenen, J., N. Bloom, M. Draca, T. Kretschmer, and R. Sadun (2010). The Economic Impact of ICT. Available at http://cep.lse.ac.uk/textonly/_new/research/productivity/Managem ent/PDF/breugel_cStudyTheImpactofICTLSE.pdf. Centre for Economic Performance, London School of Economics.

Vu, K. M. (2011). "ICT as a Source of Economic Growth in the Information Age: Empirical Evidence from the 1996-2005 Period". Telecommunications Policy 35(4), pp. 357-372.

World Bank (2012). ICT for Greater Development Impact. http://siteresources. worldbank.org/E XTINFORMATIONANDCOMMUNICATIONANDTECHNOLOGIES/Resources/WBG_ICT_Strategy-2012.pdf.

- (2014). World Development Indicators 2014. http://data. worldbank.org/indicator. World Bank, Washington, DC. 
Yousefi, A. (2011). "The Impact of Information and Communication Technology on Economic Growth: Evidence from Developed and Developing Countries". Economics of Innovation and New Technology 20(6), pp. 581-596. 